\title{
International hotel groups and regional development in Central and Eastern Europe
}

\begin{abstract}
The influence of expanding hotel companies on economic development in host countries is one of the most under-researched aspects of the globalisation of the hotel industry. Aiming to contribute to this agenda this paper focuses on the expansion of international hotel groups into Central and Eastern Europe (CEE) after 1989 and enquires into their influence on economic upgrading in CEE following the fall of communism. The paper is grounded in the global production networks (GPN) perspective and selected assumptions of evolutionary economic geography (EEG), a combination of which is argued here to be an effective theoretical platform from which the targeted set of processes can be addressed. The paper proposes a framework for analysing the influence of the hotel industry on regional development in host economies. Four areas of influence are distinguished: direct investment and infrastructure upgrading, employment creation, knowledge transfer and forging local linkages. The first three of them are then analysed in more detail on the basis of Poland, Estonia and Bulgaria. It is demonstrated that the influence of hotel groups on regional development hinges upon the business model preferred by the group for a given hotel and, depending on various placespecific factors, it may have different manifestations in different markets. The paper also shows that it is often other actors from hotel groups' GPNs, rather than hotel groups themselves, that play a key role in creating and enhancing the value which the region captures and in influencing the path of development which the region follows.
\end{abstract}

\section{Key words}

The international hotel industry

Global production networks

Evolutionary economic geography

Business models

Regional development

Central and Eastern Europe

\section{Introduction}

The impact of the international tourism production system on economic upgrading in host countries is a growing research agenda (see e.g. Goodwin 2008, Hall and Page 2006, 2009, Shaw and Agarwal 2012, Wall and Mathieson 2006, Williams 2009). Despite that, it still 
seems to be a relatively long way until this complex set of processes is sufficiently explored and comprehensively theorised. By means of focusing on the varied ways in which international hotel groups foster regional development in host markets - one of the most under-researched aspects of the globalisation of the hotel industry - this paper aims to contribute to this important agenda both in empirical and theoretical terms. Given that the hotel industry is much more global than other service industries in terms of the number of countries covered by each large firm (Contractor and Kundu 2000), which in turn implies a variety of complex interactions between international hotel companies (and their partners) and the different contexts into which they expand, the shortage of research on the developmental impacts of hotel firms is particularly appealing. Meanwhile, the hotel sector requires much more attention if the uneven geographies of the tourism production system are to be fully accounted for.

This paper focuses on the expansion of international hotel groups into Central and Eastern Europe (CEE) after 1989 and analyses the role which the hotel industry plays in fostering economic upgrading in CEE following the collapse of communism. Four areas of impact are distinguished: direct investment and infrastructure upgrading; employment creation; knowledge transfer; and forging local linkages. Due to the shortage of space, only the first three are discussed in more detail. Simultaneously, given that regional development has been a central objective for the formerly communist states in their transition to market, the paper also investigates in what way the impact of the hotel sector on economic upgrading in CEE is integral to post-communist transformations. The following two questions are answered:

1. What is the influence of international hotel groups on regional development in CEE after $1989 ?$

2. To what extent do international hotel groups foster post-communist transformations in CEE?

Although the paper aims to generalise about the whole CEE, examples are mainly drawn from Poland - one of the biggest markets in CEE - and to a lesser extent also from Estonia and Bulgaria.

The paper is grounded in the global production networks (GPN) perspective (Coe et al 2008a, Henderson et al 2002, Hess and Yeung 2006), which because of its attention to post-entry behaviour of expanding firms (unlike e.g. eclectic paradigm and other approaches used to explain the globalisation of services before - see Faulconbridge et al 2008) is argued here to 
be a promising theoretical platform from which the impact of the hotel industry on economic development can be effectively addressed. In order to better account for the specific postcommunist nature of the CEE region, the analysis is also informed by some of the theoretical advancements associated with the 'evolutionary turn' in economic geography (Boschma and Frenken 2006, Boschma and Martin 2007, 2010, Coe 2010, MacKinnon et al 2009, Martin and Sunley 2006).

The paper draws from extensive research carried out in Poland, Estonia and Bulgaria in 2009. The research process focused on all 23 hotel groups from the world's Top 50 (Gale 2008) that were active in CEE when the research commenced and consisted of 90 interviews in total. 24 of them were conducted over the phone with HQ-level development executives from 21 out of the 23 analysed hotel groups. The following 56 interviews took place in the three focal countries (30 in Poland, 13 in Estonia and 13 in Bulgaria) and were mostly carried out faceto-face. They targeted general managers of international hotels, hotel developers and owners, local hoteliers, hotel experts from international consultant firms based in CEE, representatives of local authorities and representatives of trade unions. Ten popular business and tourist destinations across the three countries were addressed during this stage. The remaining ten interviews were carried out over the phone and targeted hotel industry representatives in other CEE countries and hotel industry consultants based outside CEE. The interviews revolved around four main themes, each of which can be equated to one of the four areas of hotel industry impact listed above. This paper addresses three of them. The results are presented theme by theme in synthesised and generalised form. The discussion is supported by selected quotations.

It is demonstrated that the influence of expanding hotel groups (and their GPNs) on regional development depends on the business model selected by the group for a given hotel (i.e. the structure of the hotel GPN in a given location) on the one hand and various place-specific features of the host market on the other. Enhanced attention to these groups of factors is thus key to understanding the post-entry implications of the worldwide expansion of hotel groups. It is also argued that the role of hotel groups is not necessarily central to the whole process. Instead, it is often other actors from their GPNs that play a critical role in creating and enhancing the value which the region captures and in influencing the path of post-communist development which the region follows. 
The paper consists of two main sections. The first one outlines the applicability of the GPN approach to research on services and economic development and proposes a framework for analysing the influence of hotel groups on regional development in host countries. The section also shows in what way the assumptions of EEG can complement the GPN framework in accounting for the processes of regional development. The second main section provides an empirical example. Focusing on the expansion of hotel groups into CEE after 1989, the section analyses the impact of the international hotel industry on economic development in CEE following the fall of communism.

\section{Global production networks (GPN) and regional development}

Developed in the early 2000s, global production networks (GPNs) is "a heuristic framework for understanding the developing geographies of the global economy" (Coe and Hess 2011, p. 130). As a broad-based approach that is "capable of grasping the global, regional and local economic and social dimensions of the processes involved in many (...) forms of economic globalisation" (Henderson et al 2002, p. 445), the GPN framework "emphasises the complex intra-, inter- and extra-firm networks that constitute all production systems, and explores how these are structured both organisationally and geographically" (Coe and Hess 2011, p. 130). In general, the architecture of the GPN framework rests upon three conceptual categories power, embeddedness and value (see Coe 2009, Henderson et al 2002, Hess and Yeung 2006 for a detailed discussion). Of critical importance to this paper is the category of value which allows the GPN framework to consider how value can be created and enhanced and to what extent it can be captured by various locations and actors. Thus, one of the central concerns of GPN analysis is "to reveal the dynamic developmental impacts that result both from the firms and the territories that they interconnect" (Coe and Hess 2011, p. 130). More specifically, the framework's perspective on regional development revolves around the concept of "strategic coupling of global production networks and regional assets, an interface mediated by a range of institutional activities across different geographical and organizational scales" (Coe et al 2004, p. 469). Attention is paid both to endogenous growth factors within the region (such as local human, technological and institutional resources that are a necessary precondition for development to take place) and to the strategic needs of the translocal actors that coordinate GPNs. If the region's assets complement a transnational firm's strategic needs a coupling process takes place. However, to bring regional development, the process of coupling requires the presence of institutional structures that would promote local assets and attract translocal actors (Coe 2009, Coe and Hess 2011, Coe et al 2004, MacKinnon 2012, Yeung 2009). 
The applicability to research on services is another key feature of the GPN framework. The research by Coe et al (2008b) who enquired into the power relations between different stakeholders in the temporary staffing industry in Poland and the Czech Republic and by Coe and Wrigley (2007) who focused on host economy impacts of expanding retail corporations can serve here as good evidence. As this paper demonstrates, the GPN framework is also particularly useful in research on the hotel industry. Thus, to set the scene, Figure 1 demonstrates in what way the international hotel industry can be theorised as a form of global production network, whereas in order to delineate different types of hotel GPNs Table 1 provides a summary of five main business models of hotel groups, each of which implies a different relation between the hotel owner and the hotel group and thus a different structure of the hotel GPN. Building upon the concept of strategic coupling and the work of Dicken (2007) who identified major dimensions of GPN impacts on host economies Figure 2 proposes a framework for analysing the impact of the international hotel industry on regional development in host countries.

$($ Figure $1+$ Table $1+$ Figure 2)

However, while the applicability of the GPN framework to research on regional development cannot be questioned, the approach is not entirely free from shortcomings. Most importantly, the GPN framework does not fully account for the historical evolution of global production networks and regional assets over time - a limitation which according to MacKinnon (2012) can be easily overcome by combining the GPN framework with evolutionary economic geography (EEG). Indeed, drawing from evolutionary economics, EEG is concerned with the spatialities of economic novelty, how the spatial structures of macro-economy are shaped by the behaviour of economic agents and how the processes of path creation and pathdependence interact to shape geographies of economic development (Boschma and Martin $2007,2010)$. In other words, shedding light on the economy as a dynamical and selftransformational system, EEG explores how the economic landscape is transformed over time (Boschma and Martin 2007).

The central concepts of EEG are path-dependence, path-creation and lock-in. The idea of path dependence assumes that the economic landscape does not tend towards a unique equilibrium but it rather evolves in ways shaped by its history and past trajectories of growth (Boschma and Martin 2010). Thus, future outcomes depend on past events (Martin and Sunley 2006). 
The idea of path-creation, in turn, suggests that actors may reproduce, transform and deviate from existing socio-economic structures, practices and development paths, or to put it more simply, that new paths of development are also possible (Martin and Sunley 2006). Finally, the concept of lock-in refers to "how regions can become 'locked-in' to existing trajectories of development as the weight of inherited investments, practices and skills inhibits their capacity to adapt to wider processes of economic change" (MacKinnon 2012, p. 233). Thus, while the concept of strategic coupling can account for the local assets which the region relies on and the role which different local actors play in stimulating further growth, the key notions of EEG draw attention to the historical context in which this growth takes place and the path of development which the region follows. In this respect, the assumptions of EEG are particularly useful in accounting for the nature of the places which various GPNs interconnect and on which they impact - something that over years has been one of the most undertheorised elements of the GPN framework (Hess and Yeung 2006, Coe et al 2008a).

Due to the fact that the traces of the communist past continue to shape the geographies of the CEE region (Smith and Timar 2010), it is not surprising that the concepts of path-dependence and path-creation play a key role in explaining the variety of post-communist paths of growth across CEE (Smith 1997, Sokol 2001). With regard to CEE, the idea of path-dependence implies that the landscape of capitalist production is constituted out of the past relations which are not replaced but simply reworked in a complex way as post-communist transformations progress (Smith 1997). Concurrently, post-communist transformations are also path-shaping processes - whereas history and legacies constrain the economic actions of actors, they do not foreclose strategic choices that are still available to them (Hausner et al 1995, Sokol 2001). In contrast, it has been only recently that the assumptions of EEG have started permeating research on the tourism economy (Brouder and Eriksson 2013). Meanwhile, as Brouder (2014) notes, there are legitimate reasons to expect that evolutionary approaches to tourism research can enhance the theoretical development of tourism studies. The research by Gill and Williams (2011) on the role of different tourism stakeholders in influencing the tourist development of Whistler (Canada) further supports this assertion. Most importantly, because of the dynamic nature of the CEE capitalisms, the concepts of path-dependence and pathcreation are particularly helpful in research on tourism in CEE. The work of Williams and Balaž (2000, 2002), who analysed the impact of communist legacies on the post-1989 development of the tourism industry in the Czech Republic and Slovakia, is a good example. 
Bringing together the GPN perspective and the key assumptions of EEG, this paper follows MacKinnon (2012, p. 231-232) who argues that "the process of strategic coupling can be viewed in evolutionary terms, suggesting that regional institutions' capacities to bargain with TNCs will reflect the legacy of previous strategies and forms of investment". Concurrently, "[n]ew forms of strategic coupling based on the meshing of regional assets and local firms in GPNs can be seen as a key mechanism of path creation" (MacKinnon 2012, p. 234). Thus, links to external networks can provide access to extra-regional sources of innovation, investment and expertise (Coe et al 2004, MacKinnon 2012) - something that Martin and Sunley (2006) refer to as transplantation of new technologies, organisational forms and institutional arrangements from elsewhere, and which they consider a key mechanism of 'delocking'. As Brouder (2014) and Brouder and Eriksson (2013) note, the nature of knowledge transfer through tourism networks and the ability of this transfer to overcome pathdependence and lock-in is an important gap in research on the tourism production system. Thus, apart from analysing the impact of hotel groups on economic upgrading in CEE per se, this paper explores the role which hotel GPNs play in "de-locking" the regional economies of CEE from the legacies of communism.

\section{The hotel industry and economic upgrading in Central and Eastern Europe}

When in 1989 communism in Central and Eastern Europe (CEE) collapsed, the countries of the former communist bloc almost unanimously decided to embark on the path of transition from socialism to capitalism. Looking to be inserted into "at least the margins of the wider global economy" (Hudson 2000, p. 411) and hoping for a smooth closure of the wealth gap between the East and the West, the CEE states opted to implement liberal democracy and various forms of market economy (Sokol 2001). A critical role in the transition was accorded to FDI (foreign direct investment) and, more generally, the expected influx of foreign firms, both perceived as crucial components of internationalisation and demonopolisation (Bradshaw and Swain 2004, Pavlinek 2004). It was argued that large inflows of foreign firms would generate widespread industrial restructuring, foster technology and knowledge transfers, implement modern production and management strategies and create jobs, thus bringing economic upgrading at all spatial scales (Pavlinek 2004). The following section analyses the role of the hotel industry in this set of processes. The section enquires into the extent to which the processes of strategic coupling between hotel GPNs and regional assets and actors in CEE foster economic growth in CEE and help the CEE regions to overcome the post-communist path-dependence. 


\section{Direct investment and infrastructure upgrading}

Given that each new hotel project implies a large injection of capital in real estate, the most basic role that the hotel sector plays in fostering regional growth in CEE is associated with direct investment (Brown 1998, Franck 1990, Go and Pine 1995). However, whether the hotel industry is a source of external capital depends on where investors come from. Even if hotels are operated or franchised by international hotel groups, the invested capital may be local and the influence of hotel GPNs on economic upgrading may be in this respect fairly limited. Notwithstanding that, as Table 2 shows, despite the recession experienced by some countries in 2008-2009, the volume of FDI stocks in the accommodation sector has in many CEE states significantly increased in the last decade. The role of the international hotel industry as an important source of foreign investment in CEE cannot be therefore questioned. However, three potential negative aspects of this impact also should be recognised. First, the cost associated with obtaining FDI may be higher to host countries than that of local investments (e.g. as a result of tax holidays offered to foreign investors). Second, FDI in the hotel sector may contribute to the host country's dependency on foreign capital, thus affecting the country's autonomy in implementing economic policies (Dicken 2007) - something that Coe and Hess (2011) refer to as the "dark side" of strategic coupling. And third, the outflow of profits may in time outweigh the amount of capital invested initially, thus leading to considerable financial leakages (Brown 1998, Dicken 2007).

\section{(Table 2)}

Therefore, the most important kind of value that the host country captures is the development of high-quality hotel infrastructure - something that many regions of CEE still often lack. This semi-permanent character of hotel base is perfectly reflected by the concept of "spatial fixity" of tourism supply, i.e. the inability of many forms of tourism supply to relocate to different places (Urry 1990, Hall and Page 2009). As a general manager from an international hotel in Sofia observed:

"For the city it's a long-term investment. (...) And it is not something with which you can do whatever you want. If for any reason you have cheaper labour next door you move the factory. (...) But the hotel won't move because our business is local. We invest in the beginning, then we maintain it, develop it, which means we carry 
on with a certain plan to invest. (...) We can't move. We might build another hotel somewhere else, that's true, but this one will stay."

(September 2009)

Moreover, the contribution of the international hotel industry to the development of the hotel infrastructure also has an important qualitative dimension. Because international hotel groups tend to be leaders in setting modern construction standards (Mitka-Karandziej 1993), newlybuilt international hotels are often the most technologically-advanced developments in CEE. In addition, international hotels offer plenty of accompanying facilities such as leisure clubs or conference rooms, the shortage of which is still evident across CEE. A notable example is Warsaw where the biggest conference facilities are currently offered by the Hilton hotel.

Importantly, the value that the international hotel industry brings to CEE has a clear reflection in the physical landscape of cities and towns. In contrast to the obsolete post-communist hotel base, international hotels often stand out in the landscape and become hallmarks of whole districts - even in bigger cities where they are not the only new developments, the InterContinental Hotel in Warsaw and Swissôtel in Tallinn being good examples. For the same reasons, the international hotel industry contributes to the urban development of CEE cities and the regeneration of urban cores (Chang et al 1996, Watson 1991). Multiple revitalisation projects that have been undertaken by CEE cities since the post-1989 closure of inefficient state-owned plants and the subsequent abandonment of whole industrial areas are the best evidence here. The Manufaktura shopping and entertainment centre in Lodz that has been developed in the place of an old industrial district and that also includes an international hotel is a prominent example.

The role of local authorities and other institutions in CEE such as convention bureaux and tourist chambers, all of which deliberately attract hotel GPNs through promoting regional assets and exposing the region to external influences, should not be unacknowledged. The ways in which local authorities stimulate the development of the hotel sector are therefore place-specific, i.e. they depend on the path of post-communist growth followed by the region and the specific features of a given institutional environment such as the political and personal attitudes of local decision-makers and the level of bureaucracy. For instance in Estonia, where local authorities claim to have a liberal approach and try not to get involved in the growth of any private sector, the responsibilities of local authorities are usually limited to elaborating general development plans, investing in public infrastructure and conducting city marketing 
(Interview with a senior official from the City Enterprise Department, Municipality of Tallinn, June 2009). Due to the high level of centralisation, the level of involvement of local administrations is also considerably low in Bulgaria. In contrast, Polish municipalities often foster the development of the hotel industry more pro-actively. Not only do they suggest what kind of investments they expect on various plots, but they also elaborate investment offers for potential investors and cooperate with consultant firms to carry out market research and look for hotel investors and operators. However, given that the extent of such endeavours largely reflects political ambitions of local authorities, it should not be surprising that wide regional variations in this respect can be observed across Poland. While on the one hand there are active and progressive cities such as Wroclaw and Gdansk, on the other there are numerous destinations that are still far less outward-looking and that especially pertains to nonmetropolitan areas.

At the same time it is necessary to acknowledge that the development of hotel infrastructure can only bring expected results if it is synchronised in space and time with the development of other infrastructure - the infrastructure determining the city's accessibility (e.g. railways, airports), the business infrastructure (e.g. convention centres) and the entertainment infrastructure (e.g. stadiums, concert halls), which all generate demand for hotel services but which in CEE are still often "in the making" (especially in secondary destinations). While on the one hand the shortage of the other infrastructure impedes the development of hotels, on the other the development of hotels stimulates the development of the other infrastructure and fosters regional growth through enhancing the attractiveness of the city and positioning the city as a tourist/business destination. This results in a higher number of cultural, business and sport events and in an increased number of foreign investments, all of which serve as important sources of technological, organisational and institutional innovations and useful mechanisms of de-locking. Thus, hotel GPNs have the potential not only to create and enhance the value that the region captures but also to help the region multiply that value by means of expanding into the market and improving its economic image. This path-shaping potential of the hotel sector was well addressed by a development executive from an international hotel group active in CEE:

"I think it goes both ways. (...) In the early 1990s (...) internationally-branded hotels were considered to be necessary business infrastructure. And I think that was why EBRD was funding hotel projects along with office buildings. Having modern hotels (...) was necessary for Western companies to come in and do business easily. 
(...) So once you have these (...) modern hotels, then obviously it helps the growth of international business in the destination. And then, in turn, it stimulates economic development. And when the economy develops, it may create hotel development opportunities. So it goes both ways."

(November 2008)

However, although the potential of the international hotel industry to attract new businesses cannot be questioned, it is necessary to recognise that in the majority of cases the hotel industry develops in a reactive way, i.e. it follows economic development. It is for this reason why the most significant hotel sector growth in CEE can be observed in capital cities (Warsaw, Tallinn and Sofia being good examples) and other relatively well-established business destinations such as Krakow, Wroclaw or Gdansk, whereas secondary and tertiary destinations across CEE continue to suffer from a largely undeveloped (international) hotel base (e.g. Lublin in Poland, Bourgas in Bulgaria or Tartu in Estonia).

Finally, the way in which international hotel groups foster infrastructure upgrading in host destinations also depends on the group's business model. Whereas injecting foreign capital and developing the hotel infrastructure is down to hotel developers, it is hotel operators and franchisors that dictate hotel developers what standards to pursue and that play a key role in importing novelty into CEE. It is also operators and franchisors who provide a brand and enhance the market's visibility. Thus, although the role of developers in fostering economic upgrading in financial terms outweighs that of operators and franchisors, the role of hotel operators and franchisors in implementing innovations and helping the CEE economies with overcoming the post-communist path-dependence is more significant than that of developers. What further supports this assertion is that, due to the high degree of scepticism which foreign developers still often express towards CEE, hotel groups that expand into CEE mainly rely on local developers who usually do not have access to the newest technological solutions to the same extent as their foreign counterparts. Thus, it is through importing innovations that hotel GPNs initiate mechanisms of path-creation. This observation is expanded upon in the sub-section on knowledge transfer and staff training.

\section{Employment creation}

The role of the international tourism production system in generating employment has long been recognised and documented (Brown 1998, Cukier 2002, Ioannides and Timothy 2010, Liu and Wall 2006, Williams 2009). However, because of the massive unemployment that hit CEE further to the collapse of communism (Dunford and Smith 2004) and the great hopes that have been pinned in this respect on foreign firms (Pavlinek 2004), the role of the 
international hotel sector in generating employment in CEE and how it differs between different countries and various types of destinations, deserves particular attention.

The impact of hotel groups on job creation in CEE can be analysed according to two criteria the number of jobs and the quality of jobs in terms of skills, wages and labour relations. With regard to the first criterion, apart from numerous casual jobs, the most important jobs that the hotel industry generates are permanent jobs at each new hotel. Depending on the size of the hotel (i.e. the number of rooms) and the range of accompanying facilities (e.g. restaurants, spas, etc.) the number of newly-created jobs may differ widely. Whereas in Western Europe the ratio of employees per room oscillates in the range 0.3-0.5 (and is only higher in luxury hotels), owing to the low cost of labour the ratio in international hotels in CEE ranges from 0.5 to 1.0 or more (Interviews with representatives of international hotel groups active in CEE, November 2008-April 2009). Although from the employment perspective the higher ratio in CEE is a positive phenomenon, it can be expected that if the economic development in CEE progresses, the labour cost will increase and the employment ratios in CEE will have to be reduced. Despite that, as Table 3 shows, the level of direct employment in the hotel sector in the three focal countries has significantly grown in the last decade and apart from Estonia, where the financial crisis of 2008-2009 affected the hotel sector significantly, is still constantly growing.

\section{(Table 3)}

Moreover, the international hotel sector also initiates jobs indirectly, for instance through generating additional demand for local products and services (Brown 1998). This pertains to construction firms hired at the stage of property development, suppliers of food and beverage products and providers of services which hotels tend to outsource (e.g. cleaning, laundry, security). In other words, the volume of jobs created indirectly hinges upon the extent of local linkages forged by the developer and the operator. However, whether the employment created by the international hotel industry translates into a net gain of jobs for the local community also depends on potential adverse effects of the international hotel sector's expansion. As Dicken (2007) observed, the expansion of TNCs (transnational corporations) into a host economy may lead to a displacement of jobs elsewhere in the sector and a squeezing out of local firms. This is especially the case in secondary destinations across CEE where it is relatively easy for an international hotel (especially if it is the first international hotel in the 
destination) to quickly dominate the market and put some of the local competitors out of business. The Bulgarian resort destinations where international hotels are said to have a significant advantage over their local counterparts in terms of the quality of services are a good example here.

While building new hotels may impact on employment levels in CEE positively, the expansion of international hotel groups through acquiring state-owned chains or signing management or franchise agreements with existing hotels and re-branding (converting) them may sometimes have a negative influence. Given that new arrangements are usually sought when the business is not financially sustainable, reducing jobs is inevitably one of the ways in which profit-orientated operators look to achieve cost-efficiency. Because in communism many hotels were over-staffed, cutting employment is from the perspective of foreign hotel groups an economically-justified necessity in the CEE context. As a development executive from an international hotel group active in CEE explained:

"If the owner and the operator are not looking at achieving efficiency (...) what would be the point for those parties in doing new arrangements? (...) Cutting jobs [is] not a goal in itself, but (...) those things inevitably happen when [necessary]. Obviously, we don't want to terminate people's employment, but if a particular hotel has far more people on its payroll than necessary and then some people may be friends and relatives, whoever, then what would you do? What would any rational business do?"

(November 2008)

Accor's acquisition of the Polish chain Orbis in the late 1990s serves here as a good example. As a formerly state-owned enterprise, Orbis was largely over-staffed and further to its privatisation, a reduction in staff was a critical change to be made. The gradual centralisation which Accor introduced to the whole network of Orbis hotels and which resulted in the transfer of the administrative functions from the individual hotels to the central office affected the level of employment even more. In ten years the total number of jobs at Orbis dropped from over 5000 to approximately 2000. Although this decrease in employment was massive and it serves now as a striking example of negative impact, the question remains what would have happened to Orbis if it had not been acquired by a foreign group. While it might be expected that in situations like this other paths of restructuring are possible and collective layoffs may be often avoided, it should be simultaneously acknowledged that in some cases conversions and acquisitions save businesses from bankruptcy and although some jobs have to be lost others are eventually saved. 
While the role of the (international) hotel industry in generating jobs in Poland and Estonia is largely subject to the processes and mechanisms described hitherto, mainly due to seasonality, the impact of the (international) hotel industry on job creation in Bulgaria has a very specific dimension. In contrast to business hotels in Sofia that are open the whole year, leisure hotels on the coast are only open from April to September and the majority of jobs which they offer are only seasonal. Apart from managers, employees (sometimes up to $90 \%$ of staff) are made redundant when the season is over, which forces them to either register as unemployed or find temporary jobs elsewhere, e.g. in ski resorts in the mountains where they can work in the winter. Therefore, the temporary employment generated by the hotel industry in the Bulgarian resorts is not as appealing an opportunity for local communities as it normally is in bigger cities. Thus, rather than looking for differences solely between countries in CEE, it is also useful to distinguish between resorts and business destinations.

While owing to the gradual increase in the number of hotels across CEE the overall impact of the international hotel sector on employment levels in CEE can be expected to be rather positive (although, as mentioned above, it is hardly possible to measure the actual net gain of jobs), the same cannot be said about the quality of jobs that the industry generates. With the exception of managerial positions, jobs offered at hotels are usually low-paid, labourintensive and servile in nature (Baum 1993, 2007, Ioannides and Debbage 1998, Zampoukos and Ioannides 2011). Even if international hotels offer higher wages than their local competitors, they are still too low to markedly improve local people's well-being. Moreover, given that high-order decision-making functions are concentrated in hotel groups' HQs outside CEE, the development of the international hotel sector in CEE fosters "a geographical bias in the pattern of types of employment at the global scale" (Dicken 2007, p.469). By the same token, with the exception of Poland where trade unions are traditionally strong, labour in the hotel industry in CEE is very weakly organised, which often results in stricter internal requirements and lower levels of job stability (see Baum 2007).

Most importantly, similarly to injecting capital and upgrading infrastructure, different types of hotel GPNs impact on employment levels in CEE in different ways. While the quality of jobs is normally determined by the operator, it is the hotel investor whose entrepreneurial initiative creates new jobs and who therefore plays a more important role than the operator in creating employment in absolute terms. In contrast, given that both the scope of local linkages forged 
by the hotel and the position of the hotel in the local market depend on the strategic decisions made by the operator, the impact of the operator on the number of jobs generated or displaced elsewhere in the host economy is more significant than that of the hotel developer. In turn, the impact of franchisors and hotel consortia, which are usually not involved in daily operations, is almost non-existent. While the mechanisms of job-creation described in this sub-section demonstrate how the hotel industry impacts on economic development in CEE, the ways in which these mechanisms contribute to the processes of de-locking CEE from the postcommunist path-dependence are dealt with in the next sub-section.

\section{Knowledge transfer and staff training}

Technology and knowledge transfer has long been recognised as one of the most important categories of long-term impact that foreign firms may have on the host economy (Darr et al 1995, Dicken 2007, Glass and Saggi 2002). As some commentators pointed out, international hotel groups are no exception in this respect (Jacob and Groizard 2007, Pine 1992). For this reason, as valuable sources of newest standards, innovations and know-how, hotel groups play an important role also in the CEE context.

First of all, as mentioned in the first sub-section, international hotel groups tend to promote the newest technological solutions. This influence starts as early as the stage of property development when operators and franchisors advise developers on what facilities to include and how to develop and arrange them in order to create a sustainable hotel product. While 30 years ago it would probably mean no more than air-conditioning, nowadays it implies wellequipped conference rooms, sophisticated spas and various facilities offered in guest rooms such as wireless internet, play stations or pay TV. Moreover, it also pertains to different kinds of software that are used by hotels of the same brand to store and exchange operating knowledge and to organise work in the same way. However, it should be recognised that although such innovations may be largely appreciated by local business owners and operators, some technologies such as cost-rationalising software may have undesired effects on hotel workers. For instance, by means of rationalising costs and increasing labour control they may heighten the pressure on staff and thus seriously affect the quality of jobs, not to mention that for the very same reasons they may also have a negative impact on employment levels.

In contrast to the modern technology that can be often acquired independently of franchise or management packages (although many local hotels in CEE still cannot afford it), professional 
knowledge - something that has to be learnt on the spot and that has a partly tacit character is far more difficult to acquire without adequate guidance. In this respect the term 'knowledge' pertains to innovative management and marketing techniques, rules underlying the organisation of work (e.g. fire or health and safety regulations) and customer service standards which have long traditions in the West but which are still often under-developed in CEE (see Karhunen 2008 for the example of Saint Petersburg). Importantly for the CEE regions that look for new sources of novelty in order to de-lock themselves from the postcommunist path-dependence, the transfer of knowledge which hotel groups initiate also spills out beyond hotel GPNs. For instance, expatriate managers often serve as international tourism experts and help local administrations with elaborating city promotion strategies and planning destination management activities. Their expertise also often proves helpful in establishing new tourism-related legislation. Finally, customer service standards and corporate culture are acquired not only by hotel employees but also indirectly by their families and friends who subsequently export them to other sectors in the host economy (Fosfuri et al 2001).

Despite that, one of the crucial types of knowledge transfer that the CEE regions can capture is associated with the professional training provided by hotel groups to local staff. As a development executive from an international hotel group active in CEE pointed out:

\footnotetext{
"If a local person works for an international company they have the opportunity to liaise with the organisation (...) which gives them a very powerful incentive. [Our hotel group] is a machine. We have [a few thousand] hotels around the world so we have certain standard operating procedures and ways of doing things and when you are trained and taught in those procedures and those ways you become a better business person and do things the way they're done by an international company. These are then transferable to whatever you may do in your life, whether you stay with the hotel business or you do something else on your own."
}

(January 2009)

While on the one hand the professional training is firm-specific (i.e. it focuses on chainspecific procedures), it also inevitably includes general hotel knowledge. Every hotel group has a separate training system in which both kinds of knowledge are taught. Importantly, in order to secure a high level of consistency in terms of brand standards, every member of staff (regardless of the position) is offered the same level of exposure to training. Connected to this, many hotel groups also have special departments, often referred to as "universities" (e.g. Accor Academie), whose objective is to provide high-level courses for talented employees. 
Because of the shortage of professional hotel schools and the low level of development of service culture in CEE - obvious traces of the communist past which hotel groups have to deal with when expanding into CEE (Healey 1994, Johnson and Vanetti 2004) - this category of influence is particularly valuable in CEE. Its de-locking character was well captured by a hotel industry consultant from an international consultant firm active in Poland:

\footnotetext{
"We must have somewhere to draw good examples from and fortunately there are already a few sources of those [in Poland]. It's just like the Marriott in Warsaw that opened in 1989. All the people who worked there and were trained there are now scattered across the country and work now as general managers at other hotels in Warsaw and elsewhere. It's because they got this know-how from an international operator."
}

(May 2009)

The advantage of international hotels over local hotels in terms of skills and knowledge of staff is also evident in the Bulgarian resorts. Not only can international hotels provide better customer service (as mentioned before) but also, as it was the case during the financial crisis of 2008-2009 when many local hotels went bankrupt, they are able to keep higher occupancy rates, perform better and thus more easily survive periods of economic downturn.

Despite that, just like with technology, the transfer of Western know-how should not be considered all-positive. Indeed, there is risk that local habits and ways of doing business are not always accounted for by international hotel groups which tend to rely on strictly predefined procedures. Assuming that even the most effective standards cannot be applied to the same degree all over the world, too high a level of standardisation may often restrict individual initiatives of local workers. In contrast to Poland and Bulgaria where local employees are often considered by foreign managers to be ambitious, open to innovations and willing to learn, problems like this can be observed in Estonia where standardisation is deemed to clash with the culture and mentality of Estonian staff (Interview with a senior official from the City Enterprise Department, Municipality of Tallinn, June 2009). Therefore, although some generalisations about the whole CEE can be easily made, more detailed research would be necessary to comprehensively explore the need for and the effectiveness of knowledge transfer in the hotel industry at different spatial scales and in different cultural and social contexts across CEE. 
Finally, it is also worth acknowledging that the technology and knowledge which the hotel sector imports to CEE are more easily diffused in the host economy than those imported by the industries where technological achievements are strictly guarded for commercial purposes. Due to the fact that such knowledge may be difficult to obtain without the international hotel industry's involvement, the value that the CEE economies capture is in the context of postcommunist transformations an important engine of economic development and a powerful (although often unappreciated) mechanism of de-locking. Moreover, given that knowledge transfer is to a larger extent initiated by hotel operators, franchisors and hotel consortia, rather than by hotel developers, and that they share this knowledge with hotel developers which in CEE are still predominantly local firms, the hotel sector is a good example of how external forces (in this case hotel GPNs) can influence the path of development which a given economy follows.

\section{Conclusions}

In order to address one of the most under-researched aspects of the globalisation of the hotel sector - the impact of the hotel industry on economic development - and to contribute to the general understanding of the tourism production system's developmental impacts, this paper focused on the role of international hotel groups in stimulating regional development in CEE and analysed how the processes of strategic coupling between hotel GPNs and local firms and assets foster post-communist transformations in CEE. Four different areas of impact have been distinguished: direct investment and infrastructure upgrading, employment creation, knowledge transfer and forging local linkages. The first three have been analysed in detail.

The paper has argued that the ways in which the value is created, enhanced and captured for the benefit of CEE regions hinge upon the structure of the hotel GPN in a given location (i.e. the business model selected by the hotel group for a given hotel and the relations between the hotel group and the hotel owner) and various place-specific institutional characteristics of the host country/region. It has been shown that the role of hotel groups is not always crucial as it is often other actors from their GPNs (notably hotel developers) that play a key role in fostering economic upgrading. However, although the most obvious categories of influence such as injecting capital and creating new jobs are down to developers, the important role of operators, franchisors and hotel consortia also has to be acknowledged. Indeed, by means of training hotel cadres and importing the newest technological solutions hotel operators and franchisors have the potential to foster economic development in CEE in no less important 
way. Despite that, some negative areas of influence can also be identified - repatriating profits and fostering the displacement effect are perhaps the most notable examples.

Most importantly, because of the knowledge transfer which hotel operators and franchisors initiate in CEE, the international hotel industry can be an important source of novelty to the CEE region, thus helping the national and regional economies of CEE to break away from the legacies of communism and develop in a more path-shaping way. Therefore, not only does the influx of international hotel groups into CEE help the CEE countries to connect with the wider networks of the global economy, but it also functions as a mechanism of de-locking the CEE economies from the post-communist path-dependence.

Finally, the paper also has important theoretical and methodological implications. In theoretical terms it has been demonstrated that the assumptions of EEG can compensate for some of the shortcomings of the GPN approach and, if combined with the concept of strategic coupling (as suggested by MacKinnon 2012), they can help the GPN framework to more effectively address the processes of regional development. Thus, while the concepts of pathdependency and lock-in account for the historical factors that affect a given territory's trajectory of growth, the concept of path-creation is particularly helpful in accounting for the effects which various GPNs can have on a given place when they couple up with local actors and assets. Because of the path-dependent nature of post-communist transformations in CEE and the important role of external processes in how the countries of CEE develop, the CEE region proves to be a good territorial case with regard to which a combination of GPN and EEG can be operationalised. By the same token, the international hotel sector serves as a good sectoral case through which the impact of external processes on regional development can be investigated in detail. In methodological terms, in turn, the paper has shown that while it is relatively easy to identify various mechanisms of regional development which the hotel industry initiates, it is difficult (if possible at all) to measure their scale and evaluate the net value which the host economy captures. Although the paper has aimed to focus on the issue of regional development empirically - something that is very rarely looked at "on the ground" more research is required if the processes of regional development in general and the influence of the tourism production system on economic upgrading in host economies in particular are to be comprehensively accounted for. 


\section{References}

Baum, T. (1993) Human resource issues in tourism: an introduction, in: Baum, T. (ed.) Human Resource Issues in International Tourism, Oxford: Butterworth-Heinemann, pp. 3-21

Baum, T. (2007) Human resources in tourism: still waiting for change, Progress in Tourism Management, 28, 6, pp. 1383-1399

Boschma, R., Frenken, K. (2006) Why is economic geography not an evolutionary science ? Towards an evolutionary economic geography, Journal of Economic Geography, 6, pp. 273302

Boschma, R., Martin, R. (2007) Editorial: Constructing an evolutionary economic geography, Journal of Economic Geography, 7, pp. 537-548

Boschma, R., Martin, M. (2010) The aims and scope of evolutionary economic geography, in: Boschma, R., Martin, R. (eds.) The Handbook of Evolutionary Economic Geography, Cheltenham: Edward Elgar, pp. 3-39

Bradshaw, M., Swain, A. (2004) Foreign investment and regional development, in: Bradshaw, M., Stenning, A. (eds.) East Central Europe and the Former Soviet Union, Harlow: Pearson, pp. 59-86

Brouder, P. (2014) Evolutionary economic geography: a new path for tourism research?, Tourism Geographies, 16, 1, pp. 2-7

Brouder, P., Eriksson, R. (2013) Tourism evolution: latent synergies of evolutionary economic geography and tourism studies, Annals of Tourism Research, 43, pp. 370-389

Brown, F. (1998) Tourism Reassessed: Blight or Blessing?, Oxford: Butterworth-Heinemann

Chang, T., Milne, S., Fallon, D., Pohlmann, C. (1996) Urban heritage tourism: the globallocal nexus, Annals of Tourism Research, 23, pp. 284-305

Coe, N. (2009) Global production networks, in: Kitchin, R., Thrift, N. (eds.) The International Encyclopedia of Human Geography, Oxford: Elsevier, pp. 556-562

Coe, N. (2010) Geographies of production I: an evolutionary revolution?, Progress in Human Geography, 35, 1, pp. 81-91

Coe, N., Dicken, P., Hess, M. (2008a) Global production networks: realizing the potential, Journal of Economic Geography, 8, pp. 271-295

Coe, N., Hess, M. (2011) Local and regional development: a global production networks approach, in: Pike, A., Rodriguez-Pose, A., Tomaney, J. (eds.) Handbook of Local and Regional Development, London: Routledge, pp. 128-138 
Coe, N., Hess, M., Yeung, H., Dicken, P., Henderson, J. (2004) 'Globalizing' regional development: a global production networks perspective, Transactions of the Institute of British Geographers, New Series, 29, pp. 468-484

Coe, N., Johns, J., Ward, K. (2008b) Flexibility in action: the temporary staffing industry in the Czech Republic and Poland, Environment and Planning A, 40, pp. 1391-1415

Coe, N., Wrigley, M. (2007) Host economy impacts of transnational retail: the research agenda, Journal of Economic Geography, 7, pp. 341-371

Contractor, F., Kundu, S. (2000) Globalization of hotel services: an examination of ownership and alliance patterns in a maturing service sector, in: Aharoni, Y., Nachum, L. (eds.)

Globalization of Services, London: Routledge, pp. 296-319

Cukier, J. (2002) Tourism employment issues in developing countries: examples from Indonesia, in: Sharpley, R., Telfer, D. (eds.) Tourism and Development: Concepts and Issues, Clevedon: Channel View Publications, pp. 165-201

Cunill, O. (2006) The Growth Strategies of Hotel Chains: Best Business Practices by Leading Companies, New York: The Haworth Hospitality Press

Darr, E., Argote, L., Epple, D. (1995) The acquisition, transfer and depreciation of knowledge in service organizations: productivity in franchises, Management Science, 41, pp. 1750-1762.

Dicken, P. (2007) Global Shift: Mapping the Changing Contours of the World Economy, $5^{\text {th }}$ edition, London: Sage

Dunford, M., Smith, A. (2004) Economic restructuring and employment change, in: Bradshaw, M., Stenning, A. (eds.) East Central Europe and the Former Soviet Union, Harlow: Pearson, pp. 33-58

Faulconbridge, J., Hall, S., Beaverstock, J. (2008) New insights into the internationalization of producer services: organizational strategies and spatial economies for global headhunting firms, Environment and Planning A, 40, pp. 210-234

Fosfuri, A., Motta, M., Ronde, T. (2001) Foreign direct investment and spillovers through workers' mobility, Journal of International Economics, 53, pp. 205-222

Franck, C. (1990) Tourism investment in Central and Eastern Europe, Tourism Management, 11, pp. 333-338

Gale, D. (2008) Hotels' 325, Hotels, 7, pp. 38-52

Gill, A., Williams, P. (2011) Rethinking resort growth: understanding evolving governance strategies in Whistler, B.C., Journal of Sustainable Tourism, 19, 4-5, pp. 629-648

Glass, A., Saggi, K. (2002) Multinational firms and technology transfer, Scandinavian Journal of Economics, 104, pp. 495-513 
Go, F., Pine, R. (1995) Globalization Strategy in the Hotel Industry, New York/London: Routledge

Goodwin, H. (2008) Tourism, local economic development and poverty reduction, Applied Research in Economic Development, 5, pp. 55-64

Hall, C., Page, S. (2006) The Geography and Tourism \& Recreation: Environment, Place and Space, $3^{\text {rd }}$ edition, Abingdon: Routledge

Hall, C., Page, S. (2009) Progress in Tourism Management: from the geography of tourism to geographies of tourism - a review, Tourism Management, 30, 1, pp. 3-16

Hausner, J., Jessop, B., Neilsen, K. (eds.) (1995) Strategic Choice and Path-dependency in Post-socialism, Aldershot: Edward Elgar

Healey, N. (1994) The transition economies of Central and Eastern Europe: a political, economic, social and technological analysis, The Columbia Journal of World Business, 29, pp. 61-70

Henderson, J., Dicken, P., Hess, M., Coe, N., Yeung, H. (2002) Global production networks and the analysis of economic development, Review of International Political Economy, 9, pp. 436-464

Hess, M., Yeung, H. (2006) Guest editorial, Environment and Planning A, 38, pp. 1193-1204

Hudson, R. (2000) One Europe or many? Reflections on becoming European, Transactions of the Institute of British Geographers, 25, pp. 409-426

Ioannides, D., Debbage, K. (1998a) Introduction: exploring the economic geography and tourism nexus, in: Ioannides, D., Debbage, K. (eds.) The Economic Geography of the Tourist Industry: A Supply-side Analysis, London \& New York: Routledge

Ioannides, D., Timothy, D. (2010) Tourism in the USA: A Spatial and Social Synthesis, London: Routledge

Jacob, M., Groizard, J. (2007) Technology transfer and multinationals: the case of Balearic hotel chains' investments in two developing economies, Tourism Management, 28, pp. 976992

Johnson, C., Vanetti, M. (2004) Market developments in the hotel sector in Eastern Central Europe, Advances in Hospitality and Leisure, 1, pp. 153-175

Karhunen, P. (2008) Managing international business operations in a changing institutional context: the case of the St. Petersburg hotel industry, Journal of International Management, 14 , pp. $28-45$

León-Darder, F., Villar-Garcia, C., Pla-Barber, J. (2011) Entry mode choice in the internationalization of the hotel industry: a holistic approach, The Service Industries Journal, 31 , pp. $107-122$ 
Liu, A., Wall, G. (2006) Planning tourism employment: a developing country perspective, Tourism Management, 27, pp. 159-170

Martin, R., Sunley, P. (2006) Path dependence and regional economic evolution, Journal of Economic Geography, 6, pp. 395-437

MacKinnon, D. (2012) Beyond strategic coupling: reassessing the firm-region nexus in global production networks, Journal of Economic Geography, 12, pp. 227-245

MacKinnon, D., Cumbers, A., Pike, A., Birch, K., McMaster, R. (2009) Evolution in Economic Geography: Institutions, Political Economy, and Adaptation, Economic Geography, 85, 5, pp. 129-150

Mitka-Karandziej, U. (1993) Hotelarstwo [The hotel industry], unpublished manuscript

Niewiadomski, P. (2013) The globalisation of the hotel industry and the variety of emerging capitalisms in Central and Eastern Europe, European Urban and Regional Studies, published online on $18^{\text {th }}$ September 2013, DOI: $10.1177 / 0969776413502658$, p. $1-22$

Niewiadomski, P. (2014) Towards an economic-geographical approach to the globalisation of the hotel industry, Tourism Geographies, 16, 1, pp. 48-67

Pavlinek, P. (2004) Regional development implications of foreign direct investment in Central Europe, European Urban and Regional Studies, 11, pp. 47-70

Pine, R. (1992) Technology transfer in the hotel industry, International Journal of Hospitality Management, 11, pp. 3-22

Shaw, G., Agarwal, S. (2012) Changing geographies of coastal resorts: development processes and tourism spaces, in: Wilson, J. (ed.) The Routledge Handbook of Tourism Geographies, London: Routledge, pp. 240-248

Smith, A. (1997) Breaking the old and constructing the new? Geographies of uneven development in Central and Eastern Europe, in: Lee, R., Wills, J. (eds.) Geographies of Economies, London: Edward Arnold

Smith, A., Timar, J. (2010) Uneven transformations: space, economy and society 20 years after the collapse of state socialism, European Urban and Regional Studies, 17, pp. 115-125

Sokol, M. (2001) Central and Eastern Europe a decade after the fall of state-socialism: regional dimensions of transition processes, Regional Studies, 35, pp. 645-655

Urry, J. (1990) The Tourist Gaze: Leisure and Travel in Contemporary Societies, London: Sage

Wall, G., Mathieson, A. (2006) Tourism: Change, Impacts and Opportunities, Harlow: Prentice Hall

Watson, S. (1991) Gilding the smokestacks: the new symbolic representations of deindustrialized regions, Environment and Planning D: Society and Space, 9, pp. 59-70 
Williams, A., Balaz, V. (2000) Privatisation and the development of tourism in the Czech Republic and Slovakia: property rights, firm performance and recombinant property, Environment and Planning A, 32, pp. 715-734

Williams, A., Balaž, V. (2002) The Czech and Slovak Republics: conceptual issues in the economic analysis of tourism in transition, Tourism Management, 23, pp. 37-45

Williams, S. (2009) Tourism Geography: A New Synthesis, $2^{\text {nd }}$ edition, London: Routledge

Wrigley, N., Coe, N., Currah, A. (2005) Globalizing retail: conceptualizing the distributionbased transnational corporation (TNC), Progress in Human Geography, 29, pp. 437-457

Yeung, H., (2009) Regional development and the competitive dynamics of global production networks: an East Asian perspective, Regional Studies, 43, pp. 325-351

Zampoukos, K., Ioannides, D. (2011) The tourism labour conundrum: agenda for new research in the geography of hospitality workers, Hospitality \& Society, 1, 1, pp. 25-45 
Figure 1. A stylised example of an international hotel group's global production network. Source: Niewiadomski (2013, p. 6, Fig. 1)




Figure 2. Strategic coupling in the hotel industry and hotel industry host economy impacts. Source: Own elaboration on the basis of Coe (2009, p. 560, Fig. 2) and Dicken (2007, p. 461, Fig. 16.4)

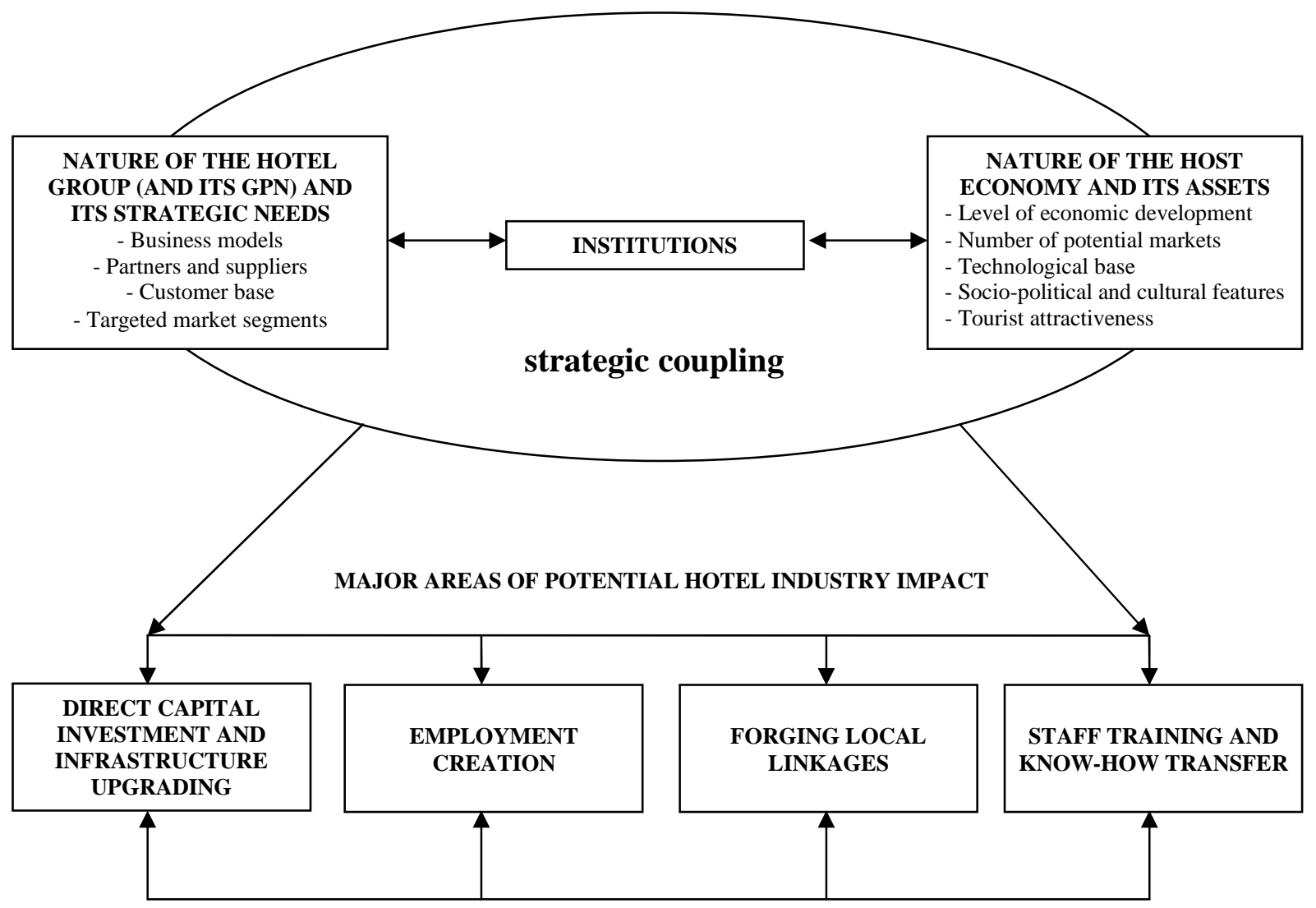

INTERRELATIONSHIPS 
Table 1. Five main business models of international hotel groups. Source: Own elaboration on the basis of Cunill (2006), Go and Pine (1995), León-Darder et al (2011) and Niewiadomski (2014)

\begin{tabular}{cl}
\hline $\begin{array}{c}\text { BUSINESS } \\
\text { MODEL }\end{array}$ & FEATURES \\
\hline Operator owning & - The hotel is both owned and operated by a given hotel group (i.e. hotel industry FDI) \\
Managing & - A high-commitment model and the slowest mode of expansion \\
- The owner employs a hotel group to operate the business \\
- A medium-commitment model \\
Franchising & - A hotel group rents the property in order to operate the business independently \\
& - A high-commitment model \\
Hotel consortia & - A low commitment model and the quickest mode of expansion \\
& - The hotel joins an affiliation of independent hotels to jointly conduct marketing activities \\
\end{tabular}


Table 2. Hotel and restaurant (2002-2006) and accommodation and food service activities (20082010) FDI stocks in selected CEE countries (in millions of Euro), Source: Own elaboration on the basis of data retrieved in September 2014 from http://epp.eurostat.ec.europa.eu

\begin{tabular}{lccccc}
\hline \multicolumn{1}{c}{ COUNTRY } & $\mathbf{2 0 0 2}$ & $\mathbf{2 0 0 4}$ & $\mathbf{2 0 0 6}$ & $\mathbf{2 0 0 8}$ & $\mathbf{2 0 1 0}$ \\
\hline BULGARIA & 63 & 97 & 243 & 558 & 677 \\
CZECH REPUBLIC & 419 & 397 & 445 & 479 & 626 \\
LITHUANIA & 57 & 56 & 58 & 89 & 61 \\
POLAND & 275 & 427 & 512 & - & 850 \\
SLOVENIA & - & 17 & 22 & 39 & 30 \\
\hline
\end{tabular}


Table 3. Employment in the hotel sector in Poland, Estonia and Bulgaria in 2004-2012, Source: ${ }^{1}$ www.stat.gov.pl, ${ }^{2}$ www.stat.ee, ${ }^{3}$ www.nsi.bg (data retrieved in September 2014)

\begin{tabular}{|c|c|c|c|c|c|}
\hline & 2004 & 2006 & 2008 & 2010 & 2012 \\
\hline POLAND $^{1}:$ & & & & & \\
\hline $\begin{array}{l}\text { Hotels and restaurants (2004-2006) } \\
\text { Accommodation and catering (2010-2012) }\end{array}$ & 250000 & 289000 & - & 303000 & 316000 \\
\hline $\begin{array}{l}\text { ESTONIA }^{2}: \\
\text { Accommodation } \\
\text { BULGARIA }^{\mathbf{3}} \text { : }\end{array}$ & 3100 & 7200 & 7700 & 7000 & 6200 \\
\hline $\begin{array}{l}\text { Hotels and restaurants (2004-2006) } \\
\text { Accommodation and food service activities } \\
(2008-2012)\end{array}$ & 79489 & 91212 & 108878 & 110834 & 113397 \\
\hline
\end{tabular}

